\title{
«АНТИФОРМАЛИСТИЧЕСКИЙ РАЁК» ДМИТРИЯ ШОСТАКОВИЧА В ИНСТРУМЕНТОВКЕ БОРИСА ТИЩЕНКО
}

Серов Юрий Эдуардович

Санкт-Петербургское музыкальное училище имени М. П. Мусоргского,

преподаватель

\section{ANTIFORMALISTIC RAREE-SHOW BY DMITRY SHOSTAKOVICH: ORCHESTRATION OF BORIS TISHCHENKO}

Yuri Serov

St. Petersburg Mussorgsky Music College,

Professor

\begin{abstract}
Аннотация. В статье анализируется партитура выдающегося отечественного композитора второй половины $\mathrm{XX}$ века Бориса Ивановича Тищенко. Будучи учеником, сподвижником и другом Дмитрия Дмитриевича Шостаковича, он в 1989 году первым оркестровал его «подпольную» кантату «Антиформалистический раек».

Annotation. The article analyzes the score of Boris Ivanovich Tishchenko, an outstanding Russian composer of the second half of the 20th century. As a pupil, associate and friend of Dmitry Dmitrievich Shostakovich, in 1989 he was the first to orchestrate the underground cantata Antiformalist Raree-show by Shostakovich.

Ключевые слова. Борис Тищенко, Дмитрий Шостакович, Антиформалистический раек, симфонический оркестр.

Keywords. Boris Tishchenko, Dmitry Shostakovich, Antiformalistic Raree-show, symphony orchestra.
\end{abstract}

Помимо своего собственного внушительного каталога сочинений для оркестра самых различных составов, Борисом Тищенко сделан обширный ряд инструментовок произведений других композиторов: оркестровка и редакция оперы Монтеверди «Коронация Поппеи» (1967); расшифровка двух пьес для оркестра гагаку (1972); оркестровка трех хоров из музыки С. Прокофьева к трагедии А. Пушкина «Борис Годунов» (1972); оркестровка вокального цикла Д. Шостаковича «Сатиры» на стихи Саши Черного (1972); оркестровка вокального цикла Д. Шостаковича «Четыре стихотворения капитана Лебядкина» на тексты Ф. Достоевского (1986); оркестровка оперы Д. Шостаковича «Антиформалистический раек» (1989); оркестровка 4 романсов Э. Грига (1991); оркестровка 7 песен Г. Малера (1993); оркестровка «Пяти романсов на слова из журнала “Крокодил”» Д. Шостаковича (2005); оркестровка «Музыкальной эскапады» И. Шлайна (2005); Lamento, оркестровка III части фортепианной сонаты №29 Л. ван Бетховена для арфы и струнного оркестра (2005); оркестровка «Вокализа-этюда» (в виде хабанеры) М. Равеля (2005).

Хорошо известно, что «Антиформалистический раёк» ${ }^{1}$ Дмитрия Шостаковича стал своего рода художественным откликом на развязанную зимне-весеннюю 1948 года кампанию по борьбе с формализмом в музыке и, одновременно, - творческим свидетельством непосредственного участника тех событий, глубоко внутренним литературно-музыкальным ответом, бескомпромиссной сатирой на все случившееся. И это совершенно особый вид вокального искусства, небольшая кантата или камерная опера, текст которой, написанный на «злобу дня», хоть и потерял свою актуальность, вызывает неподдельный интерес живостью и, ставшими уже историческими, деталями и подробностями. Нет никаких сомнений в том, что «Раёк» по своим стилевым характеристикам находится в одном ряду с театральными капустниками, причем в самом строгом значении этого понятия: самодеятельное (домашнее), как правило, - для узкого круга «своих», шуточное представление, в основе которого юмор, пародия и сатира. Молодой Шостакович должен был познакомиться с подобными спектаклями во времена своей кипучей деятельности в драматических театрах.

Необходимо отметить, что именно текст Шостаковича является главной составляющей произведения, музыка лишь предельно лаконично его иллюстрирует. «Раёк» - сочинение скорее литературное, чем музыкальное. «В либретто своего "Райка" Шостакович вложил — помимо “первоисточников" — много собственных жизненных и лингвистических наблюдений, юношеского увлечения раёшным стихом, остроумной игры со словом, литературных реминисценций» [13, с. 97]. Шостакович уловил раёшное в самой форме тех заседаний и совещаний, унылый и балаганный одновременно «протокольный ритуал этих идеологических действ - c “ведущим", который поочередно представляет ораторов, и внимающей публикой — всерьез воспроизводил сценарий народного ярмарочного райка с зазывающим Дедом-раёшником, который веселым и крепким словцом описывает своих “героев”» [13, с. 98]. Связь с «Райком» Мусоргского несомненна. Основная жанровая идея — от

${ }^{1}$ «Антиформалистический раёк» для четырех басов, смешанного хора и фортепиано (1948-1968). Слова Д. Д. Шостаковича. 
автора «Бориса Годунова». Но если Модест Петрович, сочинив свой музыкальный сатирический памфлет-ответ злопыхателям «Могучей кучки», через год опубликовал его, с нетерпением ожидая отзывы, то партитура Шостаковича, по меткому выражению М. Якубова, «стала явлением потаенной советской музыки - жанра в истории русского композиторского творчества прежде не существовавшего» [13, с. 98].

В литературной основе текста лежат подлинные высказывания партийных лидеров (несомненно сходство Единицына со Сталиным, Двойкина с Ждановым - главным действующим лицом событий 1948 года, а Тройкина - с Шепиловым), их характерные речевые интонации, даже неправильные ударения в словах. Но впечатляют, скорее, не подлинные цитаты (хотя и они - поразительная примета времени, документ, свидетельство очевидца), а метко схваченная, блестяще литературно переданная общая речевая стилистика действующих лиц и различных комментариев, стилистика всего советского официоза, вошедшего в плоть и кровь страны. Острая проницательность, о которой мы говорим в связи с музыкальными произведениями Шостаковича, распространяется и на его литературную деятельность. И наоборот, литература вошла в его музыку настолько глубоко и полно, что порою грань едва заметна или стерта вовсе.

В музыке «Райка» большую роль играют различные цитаты. Так, во время выступления Единицына и Двойкина постоянно звучит традиционный для подобного рода собраний туш; слово Единицына во многом основано на мелодии народной грузинской песни «Сулико», горячо любимой грузином Сталиным; в заключительном эпизоде речи Двойкина использован популярный кавказский танец «Лезгинка»; выступление Тройкина начинается с мелодии русской народной песни «Камаринская», а затем последовательно звучат интонации песни Тихона Хренникова из кинофильма «Верные друзья», русская народная песня «Калинка» и, наконец, в заключительной сцене с хором - знаменитые куплеты из комической оперы Планкетта «Корневильские колокола». Во второй редакции появляется тема-монограмма композитора DSCH - напрямую отсылая слушателей к автору.

Если вокальная партия дает басу-певцу возможность «покуролесить», «поиздеваться» над словом, смыслом, интонацией, пофантазировать на политико-исторические темы (можно делать это все в костюмах, танцевать, жестикулировать, словом - лицедействовать), то задача пианиста выглядит значительно скромнее. Рояльоркестр берет на себя очень скупую, иногда даже примитивную функцию гармонической поддержки солиста и намеков на темы-шаржи, ансамблевым партнером он здесь не является, никакого симфонического развития не осуществляет. Хор также выписан очень лаконично, изображая «массовку». В домашнем концерте (предполагалась ли иная аудитория?) хоровую партию, вероятно, могли бы исполнить сами зрители: несколько раз крикнуть «асса» в такт лезгинки и похлопать в ладоши под музыку Планкетта.

И все же музыка «Райка», несмотря на нарочитую, соответствующую самому духу литературной основы упрощенность, несет в себе и некоторые важные композиторские черты Шостаковича. В разнообразных приемах произнесения слова, «омузыкаливания» речи, в широком использовании октавных унисонов, в типе фактуры, голосовой интервалики несомненны переклички с романсами из «Крокодила» и с Щредисловием к полному собранию сочинений». Включение музыкальных цитат, своеобразная коллажность, переключение внимания путем вкрапления известной интонации становятся важной составляющей позднего периода творчества композитора, а появление темы-монограммы вносит оттенок личного переживания среди полной обезличенности ходульных персонажей. Сочинение это прочно укоренено в многообразном по формам, жанрам и содержанию творчестве композитора, сплетено и связано с ним в единую и прочную музыкально-интонационную цепь.

Представляется, что «Раёк» Шостаковичем изначально создавался как оркестровое сочинение — это кантата или опера. Но обстоятельства его рождения не требовали оркестровки - на публичное исполнение не было ни единого шанса. Задачу по инструментовке стали решать уже после смерти композитора, вернее, после первого исполнения «Райка» в Вашингтоне Мстиславом Ростроповичем под рояль в 1989 году². В этом же году «Раёк» инструментовал Борис Тищенко, он был первым, кто взялся за эту работу.

Пожалуй, нет нужды в этой статье подробно рассматривать взаимоотношения Тищенко и Шостаковича. Они глубоки, интересны, разнообразны и ждут своего пытливого исследователя. Тищенко был аспирантом, учеником, последователем, а затем и другом великого композитора. Их переписка, опубликованная уже в нынешнем веке, красноречиво свидетельствует об особых творческих и человеческих связях двух музыкантов [6]. Очень выразительно высказывание Тищенко, вынесенное на обложку книги писем: «И еще я думаю, доставил ли я ему хоть немного радости своим существованием, музыкой или хотя бы этой перепиской? Если да, то я жил не зря». Для Тищенко оркестровка «Райка», этого «потаенного» сочинения Шостаковича, стала естественной

2 По некоторым сведениям, рукописная партитура, хранившаяся у музыковеда Льва Лебединского, была им передана в 1987 году за границу Мстиславу Ростроповичу, который исполнил «Антиформалистический раёк» в 1989-м в Вашингтоне на английском языке и без финала. Мстислав Леопольдович сам играл на фортепиано и одновременно дирижировал хором и солистами. Впервые в окончательной авторской редакции «Антиформалистический раёк» прозвучал 25 сентября 1989 года в Большом зале Московской консерватории в рамках концерта, посвященного 83-летию со дня рождения Д. Д. Шостаковича в исполнении Государственного камерного хора Министерства культуры СССР под управлением Валерия Полянского и солистов-вокалистов. 
потребностью, знаком любви и уважения мастеру. Как же решает композитор непростые технические, инструментальные задачи при перенесении не слишком разнообразного и красочного клавира в оркестровую плоскость?

Состав оркестра достаточно экономный: 2 флейты, 2 гобоя, 2 кларнета, фагот и контрафагот, 2 валторны, 2 трубы, 2 тромбона, туба, литавры, малый барабан, тарелки, рояль и струнные. Это не совсем типичный для Тищенко оркестр (композитор предпочитал составы циклопических размеров) - он все время помнит о вокальной основе произведения Шостаковича и использует инструменты в ансамблевом ключе, подлинно tutti эпизодов здесь не так и много. Оркестр у Тищенко - это людская масса, толпа в зале заседания, сопровождающая аплодисментами, криками и знаками одобрения выступления партийных вождей. Именно поэтому полная вертикаль появляется лишь вместе с хоровыми эпизодами, в кульминациях танцев или при исполнении туша. Жесткие, очень короткие аккорды оркестра возникают на криках хора («правильно», «принято») и многократно усиливают эту специфическую культуру массового советского общения. Подвижные бескрасочные фортепианные унисоны, на которых солисты у Шостаковича наговаривают свой текст, отданы низким струнным - альты, виолончели и контрабасы наиболее гибко могут следовать за вокальной строчкой. При этом, артикуляция струнных прописана аранжировщиком предельно детализировано, она вносит необходимое разнообразие в достаточно монотонную инструментальную палитру. Важно отметить и остроумные включения контрафагота - потрясающий эффект: элемент поддакивания в толпе. Короткие глиссандо тромбонов усиливают речевые интонации солистов, они похожи на своеобразные реплики из зала.

Рулады Двойкина (у Шостаковича в скобках стоит ремарка «острит»), иронизирующего про диссонансы («Товарищи! Своим выступлением я не имею ввиду вносить диссонансы») Тищенко трактует как барочный речитатив. «Фиоритуры» бас поет на скромных гармониях фортепианной поддержки. Двойкин, захлебывающийся от гнева, кричащий «да это, это, бормашина или музыкальная душегубка!», в оркестре обрисован буйством всевозможных и разнообразных tremolo, жужжащими frullato у медных, peзкими sforzando, шумом трещотки raganella. Смех хора, после выступления остряка Двойкина, сопровождается колкими, очень острыми staccato всех медных духовых на fff - получается отрывисто, громко, зло, вульгарно.

Такая характерная примета советских партсобраний как традиционный туш - это всегда tutti, и, пожалуй, единственное место, когда Тищенко использует оркестр в виде общей безликой массы. Изумительно сделана композитором лезгинка: «в кавказских операх лезгинка простой должна быть и известной. Лихой, обычной, популярной и обязательно кавказской». Весь танец идет под аккомпанемент струнных на staccato и pianissimo и только раз в четыре такта, на хоровые возгласы «Асса», Тищенко дает вертикальный острый и короткий аккорд всего оркестра. Вальс Тройкина сопровождается простоватым аккомпанементом медных духовых. При этом в тексте у солиста следующие слова: «Глинка, Чайковский, Римский-КорсАков, вы мелодичны, красивы, звучны». Конечно, у Тищенко в этом месте нет ничего мелодичного, наоборот, оркестр иронизирует, добавляя естественной инструментальной грубости. Канкан Планкетта из «Корневильских колоколов» - стакатный у струнных и деревянных духовых, на остром отрывистом агрессивном аккомпанементе группы медных и жесткой ритмической фигуре малого барабана, поддержанного крикливыми тарелками.

Впечатляет абсолютная самостоятельность оркестровых групп, аккомпанемент становится почти полностью ансамблевым. Выразительны подголоски духовых в самых разных сочетаниях - деревянных и медных. Композитор использует гибкие, разнообразные и абсолютно сольные приемы игры на этих инструментах. Впрочем, в оркестровку Тищенко переносит ключевые особенности своего собственного композиторского языка - он всегда изобретательно работал с оркестровыми тембрами. Каждый инструмент у него со своей особой «физиономией», с характером. Композитор изучал возможности инструментов всю жизнь и пользовался ими в полной мере. Вот и в оркестровке «Райка» он придумывает различные инструментальные «фокусы», находя точный и интересный ответ различным фактурным формулам рояля. Неожиданные раздувания звука у медных на пиццикато струнных, активные tremolo, посвистывающая в нужный момент piccolo, крикливые унисоны духовых, дребезжащее frullato, активное использование сурдин, неожиданное соло литавр, раскатистое и ритмически упругое одновременно (остальные ударные очень экономны и используются, вопреки родовым свойства инструментов, для добавления в нужный момент краски) - лишь малая часть оркестровых находок аранжировщика, насыщающих партитуру свежими интонациями.

Мы видим, что Тищенко с огромным вниманием и уважением отнесся к самой сути «Антиформалистического райка». Он не просто перекладывает клавир на партитурную бумагу, но вносит свой вклад в дело познания этого необычного сочинения Шостаковича. Инструментовка усиливает шостаковичские смыслы, сатирическую, гротесковую сторону произведения. Тищенко масштабирует «Раёк», выводит его на иную высоту, отдает дань учителю и насыщает одно из его самых загадочных произведений современным дыханием, дает ему новую жизнь. Думается, что оркестровка, выполненная Борисом Тищенко, еще заживет своей интересной концертной жизнью.

\section{Литература}


копян Л. О. Дмитрий Шостакович: опыт феноменологии творчества: монография. - СПб.: Дмитрий Буланин, 2004. $-473 \mathrm{c}$.

рановский М. Г. Музыкальные «антиутопии» Шостаковича // Русская музыка и XX век [ред.-сост. М. Арановский]. - М.: Гос. ин-т искусствоведения, 1997. - С. 213-251.

ялик М. Г. Борис Тищенко // Музыка России: сб. ст. [сост. А. В. Григорьева]. - М.: Сов. композитор, 1982. - Вып. 4. $-71-87$.

ликман И. Д. Письма к другу. Дмитрий Шостакович - Исааку Гликману. - СПб.: Композитор, 1993. - 336 с.

обрыкин Э. Ю. Музыкальная сатира в вокальном творчестве Д. Шостаковича // Проблемы музыкальной науки. М.: Сов. композитор, 1975. - Вып. 3. - С. 17-37.

исьма Дмитрия Дмитриевича Шостаковича Борису Тищенко: с комментариями и воспоминаниями адресата. СПб.: Композитор, 2016. - 52 с.

7. Сабинина М. Д. Было ли два Шостаковича? // Муз. академия. - 1997. - №4. - С. 233-237.

8. Серов Ю. Э. Автор и его время в камерно-вокальном творчестве Д. Д. Шостаковича: дис. ...канд. искусствоведения: 17.00.02. - СПб., 2020. -278 с.

корбященская О. А. Борис Тищенко: интервью Robusta. - СПб.: Композитор, 2010. - 40 с.

ищенко Б. И. Размышления о 142-м и 143-м опусах // Сов. музыка. - 1974. - № 9. - С. 40-46.

остакович Д. Д. Антиформалистический раек / Инструментовка Б. Тищенко [партитура]. Л.: Музфонд, 1989. - 47 с.

остакович Д. Д. Антиформалистический раек. Для четырех басов и смешанного хора в сопровождении фортепиано и чтеца. Слова автора / Общ. Ред. и комм. М. Якубова. - M.: DSCH, 1995. $-62 \mathrm{c}$.

13. Якубов, М. А. Очищающий смех / М. А. Якубов // Наше наследие. - 1993. - № 28. - С. 97-100. 
